\title{
EFFICACY OF CAGE PLACEMENT WITHOUT PLATE IN PATIENTS WITH CERVICAL MYELOPATHY WITH SINGLE-LEVEL AFFECTION
}

\author{
EFICÁCIA DA COLOCAÇÃO DE CAGE SEM PLACA EM PACIENTES COM MIELOPATIA \\ CERVICAL COM AFECÇÃO EM UM ÚNICO NÍVEL
}

\author{
EFICACIA DE LA COLOCACIÓN DE CAJA SIN PLACA EN PACIENTES CON MIELOPATÍA \\ CERVICAL CON AFECCIÓN DE UN SOLO NIVEL
}

Carlos Alberto Zuñiga-Mazón ${ }^{1}$, Arelhi Catalina González-Cisneros², José María Jiménez-Ávila

1. Centro Médico Nacional de Occidente, Instituto Mexicano del Seguro Social, Ortopedics, Spine Clinic, Guadalajara, Jalisco, Mexico.

2. Instituto Tecnológico y de Estudios Superiores de Monterrey. Guadalajara, Jalisco, Mexico.

\begin{abstract}
Objective: To determine the efficacy of PEEK (Poly-ether-ether-ketone) cage without plate for the treatment of single-level cervical spondylosis. Methods: Ten patients with cervical myelopathy data, with a single-level root condition, seen at the outpatient clinic of the Neurosurgery Service, operated in 2016, mean age 53 years, 6 (60\%) female, 4 (40\%) obese, 3 (30\%) smokers. The Cloward technique was used by anterior approach, discectomy, and PEEK cage placement. Results: At six months of surgery, $100 \%$ of the patients had increased intervertebral space, with a 100\% reduction in osteophytes; only one patient had dysphagia, no patient had lesion of the adjacent segment and $10 \%$ had persistent root pathology. Cervical lordosis was observed in $90 \%$ of the patients and arthrodesis in $100 \%$ of the cases. Conclusions: Anterior approach arthrodesis using PEEK cage without cervical plate is effective as a treatment of cervical myelopathy in a single level.
\end{abstract}

Keywords: Cervical vertebrae; Arthrodesis; Cervical; Cervical spondylosis.

\section{RESUMO}

Objetivo: Determinar a eficácia da do uso de cage em PEEK (poli-éter-éter-cetona), sem placa para o tratamento de espondilose cervical em um único nível. Métodos: Dez pacientes com dados de mielopatia cervical com afecção radicular em um só nível, atendidos no ambulatório do Senviço de Neurocirurgia operados em 2016, com média de idade 53 anos, 6 (60\%) do sexo feminino, 4 (40\%) obesos, 3 (30\%) tabagistas. A técnica de Cloward foi usada com acesso anterior, discectomia e colocação de cage em PEEK. Resultados: Aos seis meses de cirurgia, $100 \%$ dos pacientes tiveram aumento do espaço intervertebral, com redução de $100 \%$ de osteófitos; só um paciente teve disfagia, nenhum paciente teve lesão do segmento adjacente e 10\% tiveram persistência da patologia radicular. Verificou-se lordose cervical em $90 \%$ dos pacientes e artrodese em $100 \%$ dos casos. Conclusões: A artrodese com acesso anterior usando-se cage em PEEK sem placa cervical é eficaz como tratamento de mielopatia cervical em um único nível.

Descritores: Vértebras cervicais; Artrodese; Mielopatia; Espondilose cervical.

\section{RESUMEN}

Objetivo: Determinar la eficacia del uso de caja PEEK (poli-éter-éter-cetona) sin placa para el tratamiento de la espondilosis cervical con afección de un solo nivel. Métodos: Diez pacientes con datos de mielopatía cervical, con afección radicular a un solo nivel, vistos en la consulta externa del servicio de Neurocirugía, operados en el 2016, con edad promedio de 53 años, 6 (60\%) del sexo femenino, 4 (40\%) con obesidad, 3 (30\%) con tabaquismo positivo. Se utilizó la técnica de Cloward con abordaje vía anterior, discoidectomía y colocación de caja de PEEK. Resultados: A seis meses de la cirugía, 100\% de los pacientes tuvo aumento del espacio intervertebral, con la reducción del 100\% de osteofitos, solo un paciente presentó disfagia, en ningún paciente hubo lesión de segmento adyacente y el 10\% presentó persistencia de patología radicular. Hubo lordosis cenvical en el 90\% de los pacientes y artrodesis en el 100\% de los casos. Conclusiones: Es eficaz la artrodesis por vía anterior usando caja PEEK sin necesidad del uso de placa cervical en el tratamiento de la mielopatía cervical con afección de un solo nivel.

Descriptores: Vértebras cervicales; Artrodesis; Mielopatía; Espondilosis cervical.

\section{INTRODUCTION}

Degenerative cervical disc disease is a chronic disc lesion process initiated by microtrauma and followed by dehydration processes and biochemical changes causing rupture of the anulus, hernias, and height loss, with subsequent bone changes such as osteophytes that can cause narrowing of the canal with possible radicular or myelopathic compression of the neural elements. ${ }^{1,2}$
Cervical pain has a lifetime prevalence of $66 \%$ and is usually associated with episodes of headache and low back pain. 1,3,4

Cervical myelopathy is a spinal cord dysfunction syndrome caused by the compression of the soft tissues and the bony structures in the cervical canal of congenital, degenerative, tumoral, or traumatic causes, which produces progressive neurological symptoms. ${ }^{1,5,6}$

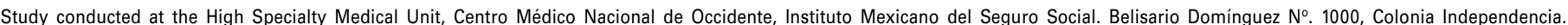
Guadalajara, Jalisco, Mexico.

Correspondence: José María Jiménez Avila. Av. Normalistas No. 442. Colinas de la Normal. Guadalajara, Jalisco México. C.P. 44270. josemajimeneza@ hotmail.com 
It primarily affects men over 50 years of age and is the most common cause of paraparesis in adults and the lesion patterns have been divided according to the portion of the spinal cord affected into the transverse lesion syndrome, the motor system syndrome, the central system syndrome, the Brown-Séquard syndrome, and brachyalgia. ${ }^{2}$

Ferguson and Caplan divided myelopathy into medial, lateral, and combined syndromes, and vascular syndrome. The physical examination may reveal hyperreflexia below the compromised level, clonus, Babinski and Hoffman pathological reflexes, and abnormal gait. Motor and sensory changes are specific to the medullary level. ${ }^{1,5-12}$

The natural history of cervical disc disease shows an average improvement of $75 \%$ with conservative treatment, ${ }^{8}$ while the natural history of cervical spondylotic myelopathy leads to gradual neurological degeneration, which is why surgical intervention should be performed as early as possible. 1,6,9,10

Treatment of disc disease of the cervical spine should begin with a conservative regimen that can include analgesics, NSAIDs, and opioids for pain control together with physical therapy for muscular control and traction for symptomatic control. Selective nerve blocks are also an option, however, cases with poor response to conservative orthopedic treatment may be candidates for surgical management. ${ }^{2,13-17}$

Anterior approach cervical discectomy is a procedure for the decompression of the neurological elements that may increase or produce instability. ${ }^{13-18}$ C5-C6 discectomy significantly increases the mobility of the segment in flexion $(66.6 \%)$, extension $(69.5 \%)$, lateral inclination (41.3\%), and axial rotation (37.9\%). ${ }^{18}$

The goal of post-discectomy arthrodesis is to reestablish the spinal structure, recovering its rigidity and stability in order to avoid anomalous movements that produce or cause progression of the deformity or that produce or maintain secondary pain. ${ }^{17}$

In cervical myelopathy, arthrodesis eliminates the dynamic factor involved in its pathogenesis and favors the tension of the yellow ligaments that insert into the posterior surface of the spinal cord. ${ }^{18,19}$

With the goal of standardizing the interbody fusion technique and eliminating the need for grafting, interbody cages of different materials were developed, both in cylindrical or parallelepipedal forms. ${ }^{19-21}$ Several biomechanical studies have demonstrated that the interbody cage behaves similarly to the tricortical iliac crest graft. ${ }^{22-24}$ These same in vitro studies also showed that the inclusion of an anterior cervical plate significantly increases stability and reduces the range of motion. ${ }^{18}$

The big problem with the cages is movement. To prevent anterior migration, it is recommended that the cage be placed $2 \mathrm{~mm}$ behind the anterior edge of the vertebral body. To prevent posterior migration, the common posterior vertebral ligament, as well as a more or less wide portion of the posterior part of the disc, can be preserved. For this reason, the relatively anterior placement of the cages can be seen in post-operative imaging studies..$^{22-27}$

PEEK (Polyether ether ketone) is a non-absorbable, semi-crystalline, polyaromatic linear polymer with qualities of strength, rigidity, durability, and resistance to the environment and with elasticity similar to bone. It is radiolucent and facilitates the observation of consolidation in simple radiographs, ${ }^{28,29}$ it is compatible with magnetic resonance, its inflammatory response is minimal, and its resistance to corrosion is excellent. However, it is harmful to growth cells and factors because the products of osteoclastic activity, alkaline phosphatase and fibroblasts, are increased following PEEK cage placement. ${ }^{28}$

Complications from anterior cervical procedures may include intraoperative neurological (1\% of cases), vascular $(<1 \%)$, esophageal $(0.2-0.9 \%)$, and dural sac $(<1 \%)$ lesions. Early postoperative complications include recurrent lesion of the laryngeal nerve, which occurs in between 1 and $11 \%$ of cases, dysphagia, which is usually temporary, and severe respiratory distress $(<1 \%)$. There is a very low frequency of infection so it has little impact on the fusion rate. Failure of the material is also an early complication associated with the technique and with an increased number of fusion levels. Pseudoarthrosis is a later complication associated with failure of the material, tobacco use, and a larger number of fused levels, and is the main cause of cervical arthrodesis revision. ${ }^{30}$

Therefore, the objective of this study is to determine the effectiveness of using the PEEK (polyether ether ketone) cage without a plate for the treatment of cervical spondylosis at a single level.

\section{METHODS}

This is a prospective, observational, longitudinal, open, non-randomized (case series) study with one year of follow-up. We identified 10 patients with cervical myelopathy with radicular involvement and no history of previous cervical surgery. They were seen in the outpatient clinic of the Neurosurgery Service and underwent anterior approach surgery during March and April 2016 using the Cloward technique for discoidectomy and PEEK cage placement.

We evaluated demographic variables such as sex, age, obesity, tobacco use, symptomatology and time of evolution, Visual Analog Scale for pain, Nurick scale, affected level, intervertebral space, presence of osteophytes, cage number, bleeding, surgical time, dysphagia, lesion of the adjacent level, persistence of sensory and motor radicular pain, hospitalization time, and follow-up conducted at 3, 6, and 12 months.

Statistical analysis consisted of conducting a descriptive evaluation estimating frequencies, percentages, and measures of central tendency and dispersion, using Excel and Epi Info v. 7.2 software.

Prior to the implementation of the protocol, it was evaluated by the Institutional Review Board for compliance with the international guidelines for conducting research projects (SIRELCIS R-2016-1301-183).

\section{RESULTS}

We analyzed 10 patients with cervical myelopathy with radicular involvement at one level, seen in the outpatient clinic of the Neurosurgery Service during the period from March to April of 2016, and who underwent anterior approach discoidectomy and PEEK cage placement using the Cloward technique. In terms of the study population demographics, the average age was 53 years, 6 (60\%) patients were female and 4 (40\%) were male, 4 (40\%) were obese, and only $3(30 \%)$ were tobacco users (Table 1$)$.

In terms of the clinical profile data, half of the cases had experienced sensory symptoms for more than 12 months, 6 (60\%) had a Visual Analog Scale for pain (VAS) score between 4 and 7 points indicating moderate pain, and 4 (40\%) with a Nurick scale score of 1 (signs of spinal cord involvement, but without changes to gait), and the most frequently affected levels were C3-C4 and C5-C6, both with $50 \%$. One hundred percent of the patients had reduced intervertebral space and $90 \%$ had osteophytes. Cage number 5 was the most often used, in $70 \%$ of the patients.

During surgery, $80 \%$ of the patients had bleeding of less than $100 \mathrm{cc}$. Surgical time was less than 2 hours in $80 \%$ of the patients and hospital stays were between 1 and 3 days in $80 \%$ of the patients (Table 2).

Twelve months after surgery, $100 \%$ of the patients had increased intervertebral space, with a 100\% reduction of osteophytes. One patient had dysphagia, which resolved spontaneously within the first 3 months following surgery. None of the patients had any lesion of the adjacent segment and only $10 \%$ presented persistent radicular pathology. There was cervical lordosis in $90 \%$ of the patients and arthrodesis in $100 \%$ of the cases (Table 3).

During follow-up in the immediate postoperative period, at three months, and at 6 months, there was a decrease in the number of patients with a VAS score indicating intense or moderate pain, thus increasing the number of patients with mild pain to $60 \%$.

As regards the Nurick scale, the number of patients rated Nurick 0 (Radicular signs and symptoms, without evidence of spinal cord involvement) increased to 50\% (Figures 1 and 2).

Table 1. Distribution of the demographic data of the population.

\begin{tabular}{c|c|c}
\hline Sex & Male & Female \\
\hline & $4(40 \%)$ & $6(60 \%)$ \\
\hline Obesity & Yes & No \\
\hline & $4(40 \%)$ & $6(60 \%)$ \\
\hline Smoking & Yes & No \\
\hline & $3(30 \%)$ & $7(70 \%)$ \\
\hline
\end{tabular}


Table 2. Clinical profile behavior and trans-surgical findings.

\begin{tabular}{|c|c|c|c|c|c|c|}
\hline Symptomatology & Motor & Sensory & Mixed & & & \\
\hline & $2(20 \%)$ & $5(50 \%)$ & $3(30 \%)$ & & & \\
\hline \multirow[t]{2}{*}{ Duration } & $\begin{array}{c}<1 \\
\text { month }\end{array}$ & $\begin{array}{c}1-6 \\
\text { months }\end{array}$ & $\begin{array}{c}6-12 \\
\text { months }\end{array}$ & $\begin{array}{c}>12 \\
\text { months }\end{array}$ & & \\
\hline & $0(0 \%)$ & $1(10 \%)$ & $4(40 \%)$ & $5(50 \%)$ & & \\
\hline \multirow[t]{2}{*}{ VAS } & $\begin{array}{c}\text { Without } \\
\text { pain }\end{array}$ & Mild pain & $\begin{array}{c}\text { Moderate } \\
\text { pain }\end{array}$ & $\begin{array}{c}\text { Intense } \\
\text { pain }\end{array}$ & & \\
\hline & $0(0 \%)$ & $0(0 \%)$ & $6(60 \%)$ & $4(40 \%)$ & & \\
\hline \multirow[t]{2}{*}{ Nurick } & 0 & 1 & 2 & 3 & 4 & 5 \\
\hline & $1(10 \%)$ & $4(40 \%)$ & $3(30 \%)$ & $1(10 \%)$ & $0(0 \%)$ & $1(10 \%)$ \\
\hline \multirow[t]{2}{*}{ Level affected } & C3-C4 & C4-C5 & C5-C6 & & & \\
\hline & $5(50 \%)$ & $0(0 \%)$ & $5(50 \%)$ & & & \\
\hline \multirow[t]{2}{*}{$\begin{array}{c}\text { Intervertebral } \\
\text { space }\end{array}$} & Reduced & & & & & \\
\hline & $\begin{array}{c}10 \\
(100 \%)\end{array}$ & & & & & \\
\hline \multirow[t]{2}{*}{ Osteophytes } & Yes & No & & & & \\
\hline & $9(90 \%)$ & $1(10 \%)$ & & & & \\
\hline \multirow[t]{2}{*}{ Cage number } & 4 & 5 & 6 & & & \\
\hline & $2(20 \%)$ & $7(70 \%)$ & $1(10 \%)$ & & & \\
\hline \multirow[t]{2}{*}{ Bleeding } & $<100 \mathrm{cc}$ & $\begin{array}{c}100- \\
200 \mathrm{cc} \\
\end{array}$ & $>200 \mathrm{cc}$ & & & \\
\hline & $8(80 \%)$ & $2(20 \%)$ & $0(0 \%)$ & & & \\
\hline \multirow[t]{2}{*}{ Surgical time } & $\begin{array}{c}<60 \\
\text { minutes }\end{array}$ & $\begin{array}{l}60-120 \\
\text { minutes }\end{array}$ & $\begin{array}{c}>120 \\
\text { minutes }\end{array}$ & & & \\
\hline & $0(0 \%)$ & $8(80 \%)$ & $2(20 \%)$ & & & \\
\hline \multirow[t]{2}{*}{ Hospital stay } & 1-3 days & 4-6 days & $>7$ days & & & \\
\hline & $8(80 \%)$ & $1(10 \%)$ & $1(10 \%)$ & & & \\
\hline
\end{tabular}

Table 3. Postsurgical clinical results.

\begin{tabular}{c|c}
\hline Intervertebral space & Increased \\
\hline Osteophytes & $10(100 \%)$ \\
\hline Dysphagia & No \\
\hline & $10(100 \%)$ \\
\hline Lesion of the adjacent segment & Yes \\
\hline & $1(10 \%)$ \\
\hline Persistence of radicular pathology & No \\
\hline & $10(100 \%)$ \\
\hline Cervical lordosis & No \\
\hline & $9(90 \%)$ \\
\hline Arthrodesis & Yes \\
\hline & $9(90 \%)$ \\
\hline & Yes \\
\hline
\end{tabular}

\section{DISCUSSION}

In the treatment of cervical myelopathy with involvement at a single level, anterior arthrodesis can be performed using a PEEK cage without the need for a cervical plate, as there was an increase of intervertebral space in $100 \%$ of the patients, with cervical lordosis in $90 \%$ and adequate arthrodesis in $100 \%$ of the patients, as well as

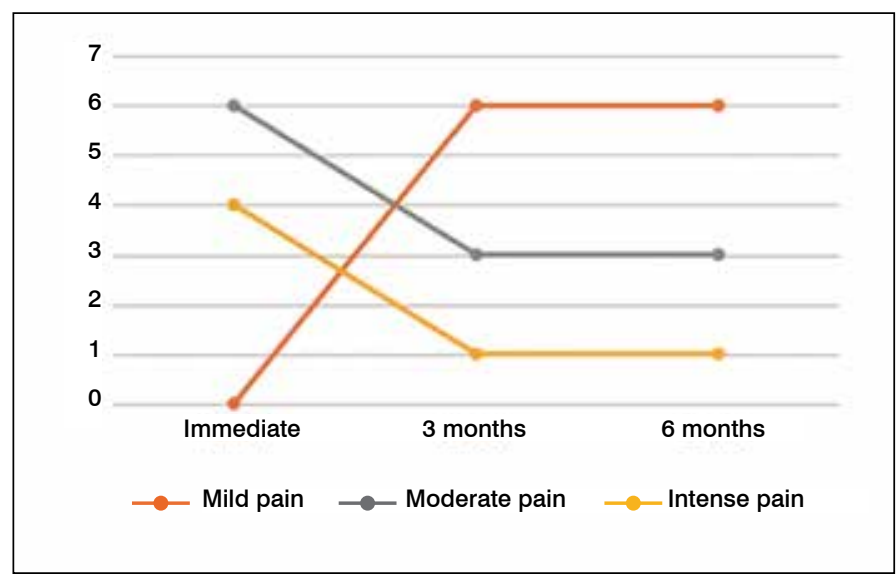

Figure 1. Postoperative behavior of the VAS.

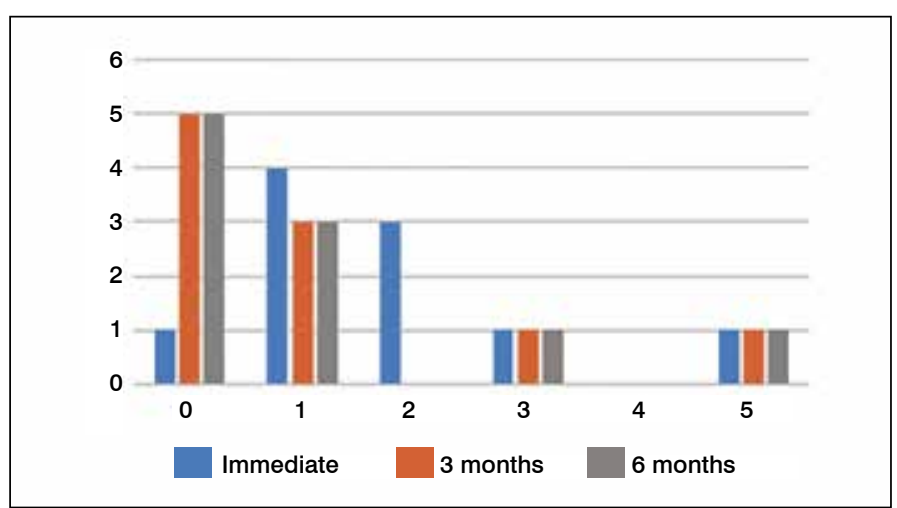

Figure 2. Postoperative behavior of the Nurick scale.

improvement of pain and the clinical profile, reducing the number of patients with moderate pain and increasing the number with mild pain in follow-ups at 3, 6, and 12 months. Similarly, there was clinical improvement, with an increase in the number of patients who moved from Nurick 1 or 2 to Nurick 0.7,8,10

Our results are similar to those of previous studies, in the predominance of female patients, the similar average age, and the fact that most of the patients were not obese. When compared to the literature, our study met the goals for increased intervertebral space, cervical lordosis, and 100\% arthrodesis. ${ }^{18,27}$

The most affected level was $\mathrm{C} 5-\mathrm{C} 6$, a result similar to that reported in the literature, although in our study involvement of C3-C4 occurred with the same frequency. The surgical time was less than 2 hours, similar to that found in the articles reviewed. The average bleeding was $187 \mathrm{cc}$, slightly more than the less than 100 cc observed in $80 \%$ of the patients in our study. ${ }^{18}$

As for the evaluation of pain, intense-moderate pain had transitioned to mild pain at 6 months following surgery, similar to the results found in the literature. ${ }^{1-3}$

We observed a reduction of the Nurick scale score of the patients, thus increasing the number of patients rated Nurick 0 . Only one patient, classified as Nurick 5, did not improve. This result confirms the description of the advanced stages of cervical myelopathy, in which the treatment is focused on preventing progression and the deterioration of patients. ${ }^{7,8,10}$

With respect to complications, only one patient presented dysphagia that resolved spontaneously, very similar as compared to the $20 \%$ of postoperative complications published in other articles. No patient required reintervention and there were no cases of CSF fistula or dysphonia from recurrent lesion of the pharyngeal nerve. Patient improvement was evaluated both clinically and by imaging, using the VAS and Nurick scales, which gave weight and value to the study. ${ }^{18,30}$ 


\section{CONCLUSION}

Anterior approach arthrodesis using the PEEK cage without the need for a cervical plate is effective in the treatment of cervical myelopathy with involvement at one level, achieving an increase in intervertebral space, conservation of lordosis, and adequate fusion, with a reduction of pain as measured by the Visual Analog Scale and clinical improvement according to the Nurick scale. The procedure has low morbidity, minimal transoperative bleeding, a shorter surgical time, and an earlier discharge from the hospital.
The use of the cage without a plate for the treatment of cervical myelopathy with involvement at only one level is appropriate for establishing adequate fusion and clinical improvement in patients with a low risk of morbidity.

All authors declare no potential conflict of interest related to this article.

CONTRIBUTION OF THE AUTHORS: Each author made significant individual contributions to this manuscript. GC wrote the abstract, did the translations, and wrote the introduction section. JA wrote the methods section and contributed to the discussion section. ZM built the tables, wrote the results section, contributed to the discussion and conclusion sections.

\section{REFERENCES}

1. Rao R. Neck pain, cervical radiculopathy, and cervical myelopathy: pathophysiology, natural history, and clinical evaluation. J Bone Joint Surg Am. 2002;84(10):1872-81.

2. Rhee JM, Yoon T, Riew KD. Cervical radiculopathy. J Am Acad Orthop Surg. 2007;15(8):486-94.

3. Côté P, Cassidy JD, Carroll L. The Saskatchewan Health and Back Pain Survey. The prevalence of neck pain and related disability in Saskatchewan adults. Spine (Phila Pa 1976). 1998:23(15):1689-98.

4. Lawrence JS. Disc degeneration. Its frequency and relationship to symptoms. Ann Rheum Dis. 1969;28(2):121-38.

5. Salvi FJ, Jones JC, Weigert BJ. The assessment of cervical myelopathy. Spine J. 2006;6(6 Suppl):182S-9S

6. Baptiste DC, Fehlings MG. Pathophysiology of cervical myelopathy. Spine J. 2006;6(6 Suppl):190S-7S.

7. Rao RD, Gourab K, David KS. Operative treatment of cervical spondylotic myelopathy J Bone Joint Surg Am. 2006;88(7):1619-40.

8. Matz PG. Does nonoperative management play a role in the treatment of cervical spondylotic myelopathy? Spine J. 2006;6(6 Suppl):175S-81S.

9. Komotar RJ, Mocco J, Kaiser MG. Surgical management of cervical myelopathy: indications and techniques for laminectomy and fusion. Spine J. 2006;6(6 Suppl):252S-67S.

10. Edwards CC, Riew KD, Anderson PA, Hilibrand AS, Vaccaro AF. Cervical myelopathy: current diagnostic and treatment strategies. Spine J. 2003:3(1):68-81.

11. Ferguson RJ, Caplan LR. Cervical spondylotic myelopathy. Neurol Clin. 1985;3:373-82.

12. Houten JK, Noce LA. Clinical Correlations of Cervical Myelopathy and the Hoffmann Sign. Journal of Neurosurgery: Spine. 2008:9(3):237-42

13. Hillard VH, Apfelbaum RI. Surgical management of cervical myelopathy: indications and techniques for multilevel cervical discectomy. Spine J. 2006;6(6 Suppl):242S-251S.

14. Steinmetz MP, Resnick DK. Cervical laminoplasty. Spine J. 2006:6(6 Suppl):274S-81S

15. Jankowitz BT, Gerszten PC. Decompression for cervical myelopathy. Spine J. 2006;66 Suppl):317S-22S

16. Medow JE, Trost G, Sandin J. Surgical management of cervical myelopathy: indications and techniques for surgical corpectomy. Spine J. 2006;6(Suppl 6):233S-241S.

17. Patil PG, Turner DA, Pietrobon R. National trends in surgical procedures for degenerative cervical spine disease: 1990-2000. Neurosurgery. 2005;57(4):753-8.
18. González-Darder JM. Development of the anterior cervical postdiscectomy arthrodesis: bone graft, plate, intersomatic cage and plate-cage. Neurocirugia (Astur). 2006;17(2):140-7.

19. Matge, G. Cervical cage fusion with 5 different implants: 250 cases. Acta Neurochir (Wien). 2002;144(6):539-49.

20. Thomé C, Krauss JK, Zevgaridis D. A prospective clinical comparison of rectangular titanium cages and iliac crest autografts in anterior cervical discectomy and fusion. Neurosurg Rev. 2004;27(1):34-41.

21. Zdeblick TA, Phillips FM. Interbody cage devices. Spine (Phila Pa 1976). 2003;28(15 Suppl):S2-7.

22. Greene DL, Crawford, NR, Chamberlain RH, Crandall D. Biomechanical comparison of cervical interbody cage versus structural bone graft. Spine J. 2003;3(4):262-9.

23. Kandziora F, Pflugmacher R, Schäfer J, Born C, Duda G, Haas NP, et al. Biomechanical comparison of cervical spine interbody fusion cages. Spine (Phila $\mathrm{Pa}$ 1976). 2001;26(17):1850-7.

24. Pflugmacher R, Schleicher P, Gumnior S, Turan O, Scholz M, Eindorf T, et al. Biomechanical comparison of bioabsorbable cervical spine interbody fusion cages. Spine (Phila Pa 1976). 2004;29(16):1717-22.

25. Buttermann GR. Prospective nonrandomized comparison of an allograft with bone morphogenic protein versus an iliac-crest autograft in anterior cervical discectomy and fusion. Spine J. 2008;8(3):426-35.

26. Malloy KM, Hilibrand AS. Autograft versus allograft in degenerative cervical disease. Clin Orthop Relat Res. 2002;(394):27-38

27. Samartzis D, Shen FH, Matthews DK, Yoon ST, Goldberg EJ, An HS. Comparison of to autograft in multilevel anterior cervical discectomy and fusion with rigid plate fixation. Spine J. 2003;3(6):451-9.

28. Wilke HJ, Kettler A, Goetz C, Claes L. Subsidence resulting from simulated postoperative neck movements: an in vitro investigation with a new cervical fusion cage. Spine (Phila Pa 1976). 2000;25(21):2762-70.

29. Vadapalli S, Sairyo K, Goel VK, Robon L, Biyani M, Khandha A, et al. Biomechanical rationale for using polyetherketone spacer for lumbar interbody fusion an infinite element. Spine (Phila Pa 1976). 2006;31(26):E992-8.

30. Patel CK, Fischgrund JS. Complications of anterior cervical spine surgery. Instr Course Lect. 2003;52:465-9. 